\title{
KAPABILITAS PRAKTIS DOMAIN PERJALANAN WISATA BALI: APLIKASI PERJALANAN WISATA BERBASIS PONSEL CERDAS
}

\author{
I Made Kusuma Negara ${ }^{1}$, Putu Agus Wikanatha Sagita ${ }^{2}$ \\ ${ }^{1}$ Email: kusuma.negara@unud.ac.id \\ Program Studi S1 Industri Perjalanan Wisata, Fakultas Pariwisata, Universitas Udayana \\ 2Email: aguswika@unud.ac.id \\ Program Studi S1 Industri Perjalanan Wisata, Fakultas Pariwisata, Universitas Udayana
}

\begin{abstract}
Bali as a popular tourist destination has succeeded in searching list of the most desirable destinations in a virtual world. Variety of information backed by increasingly technological developments has put the smartphone in a strategic position as a tour and traveling tool. The existence of the smartphone is very helpful for users to get information and meet various needs quickly. Thus, it is important to examine the preferences of tourists on the use of smartphone as tour and travel tool to Bali. The concept of information technology on tour and travel as the approach of this article. Collecting data done by questionnaire method as much as 322 people of domestic tourists and foreign tourists who analyzed descriptively. The result of this research are the smartphone not only as a tool of technology alone, but has become a tourist travel tool as well as stage social activities, creativity, and share the experience. The shift in the stages of travel has changed due to the smartphone, tourists can choose to travel online, tourists can spontaneously change the travel plans due to unexpected events, and share a moment of the trip. The limitations of this article is the online information was not integral in facilitating the information needs of tourists.
\end{abstract}

Abstrak: Bali sebagai daerah tujuan wisata yang populer telah berhasil dalam daftar pencarian tujuan yang paling diminati di dunia maya. Berbagai jelajah informasi yang didukung oleh perkembangan teknologi yang semakin canggih telah menempatkan smartphone dalam posisi strategis sebagai alat perjalanan. Keberadaan smartphone sangat membantu pengguna untuk mendapatkan informasi dan memenuhi berbagai kebutuhan dengan cepat. Dengan demikian, penting untuk dikaji preferensi wisatawan terhadap penggunaan smartphone sebagai alat perjalanan wisata ke Bali. Konsep teknologi informasi dan pariwisata digunakan untuk menjawab peranan ini. Pengumpulan data dilakukan dengan metode kuesioner sebanyak 322 orang wisatawan nusantara beserta wisatawan mancanegara yang dianalisis secara deskriptif. Dalam penelitian ini dimaknai bahwa smartphone tidak hanya sebagai alat teknologi semata, akan tetapi telah menjadi alat perjalanan wisata sekaligus panggung aktivitas sosial, kreativitas, serta berbagi pengalaman berlibur wisatawan. Pergeseran tahapan perjalanan wisata telah berubah akibat smartphone, wisatawan dapat menentukan pilihan untuk berwisata secara online, wisatawan secara spontan dapat mengubah rencana perjalanan wisata akibat kejadian tak terduga, serta berbagi momen berwisata saat itu juga. Keterbatasan asupan informasi online secara integral menjadi kendala dalam memudahkan kebutuhan informasi secara online wisatawan.

Keywords: preferences of tourists, tour and travel information system, smartphone. 


\section{PENDAHULUAN}

Bali dan pariwisata adalah dua hal yang saling melekat satu dengan yang lain. Sepertinya antara Bali dan pariwisata memang tidak dapat dipisahkan. Bahkan dalam Picard (2006) mengungkapkan reputasi Bali sebagai "surga pariwisata". Pemerintah Bali pun sangat berharap besar terhadap keberadaan sektor yang menjajikan ini, bahkan masyarakatnya pun juga sangat bertumpu pada sektor pariwisata. Sebagai destinasi wisata yang populer, Bali dapat dikatakan sukses jika dilihat dalam daftar pencarian destinasi yang paling dimininati di dunia maya. Seperti yang ditulis oleh Plautz (2016) dalam travel and leisure, kata where is Bali disebutkan sebagai pertanyaan yang paling banyak dicari dalam mesin pencari google di tahun 2016. Informasi-informasi tentang keindahan Bali selalu menjadi buah bibir dan kenangan yang eksotis dalam website maupun blog bagi mereka yang telah sempat mengunjunginya. Dalam beberapa informasi yang tampak dalam website maupun blog, menyatakan Bali memiliki pantai yang indah, penduduknya yang terkenal ramah, serta budaya yang memilki nilai keunikan tersendiri. Jika ditilik dalam sejarah perkembangan pariwisata Bali, semua itu sudah menjadi daya tarik dunia sejak dahulu kala, ketika pertama kalinya wisatawan asing menginjakkan kakinya di Bali pada tahun 20-an. Beragam julukan disandang Bali, diantaranya "Surga Terakhir" (The Last Paradise), "Pulau Dewata" (The Island of The God) dan sebagainya. Dengan kunjungan wisatawan asing dan domestik yang relatif meningkat setiap tahunnya, sangat tidak berlebihan kalau Majalah Time and Travel Leisure menganugerahkan Bali sebagai pulau wisata terbaik di dunia.

Dalam era informasi yang semakin terbuka yang juga ditunjang oleh kemajuan teknologi, mengakibatkan akses informasi menjadi tiada batas. Bahkan keberadaan teknologi komputasi yang canggih, telah menjadikannya sebagai alat perjalanan wisata (Dickinson et al, 2014). Sistem informasi perjalanan wisata Bali berbasis web yang banyak ditemukan di dunia maya melalui mesin pencari, hanya dapat berjalan jika terdapat peramban (browser) dan koneksi internet. Keberadaan berbagai website yang mengulas tentang Bali dengan ragam tampilan yang memukau, begitu dahsyat mendobrak keterbukaan informasi dengan harapan menggugah keinginan calon wisatawan untuk secara aktual melakukan perjalanan wisata. Bali juga telah memiliki eKios yang tersebar pada destinasi wisata, seperti Tanah Lot, Sangeh, dan destinasi lainnya. E-Kios menampilkan berbagai macam informasi bagi wisatawan terkait akses menuju destinasi, informasi produk wisata, tempat menginap, kebutuhan makan dan minum, akses keuangan, akses kesehatan. Temuan Sudarma (2009) mengungkapkan bahwa persepsi wisatawan terhadap efektivitas e-Kios pariwisata Bali adalah kurang efektif. Hal ini disebabkan harapan wisatawan terhadap pelayanan e-Kios pariwisata sebagai media informasi tidak sesuai dengan jasa apa yang dapat diberikan e-Kios. Tampilan informasi yang kurang dinamis dan menarik juga menjadi salah satu keterbatasan keberadaan eKios di Bali. Wisatawan mengharapkan informasi yang menarik, baik dengan display video, foto-foto, dokumen budaya, serta kegiatan spiritual di Bali. Wisatawan yang akan merencanakan liburannya ke Bali, tentunya akan mengakses informasi sebanyakbanyaknya tentang Bali (pre travel), ketika berada di Bali (on the way), dan setelah meninggalkan Bali (after trip). Ketika wisatawan menceritakan pengalaman berwisata mereka di Bali melalui smartphone, hal ini akan berdampak positif terhadap kepercayaan pengalaman berwisata sebagai kekuatan promosi dan kepuasan wisatawan itu sendiri (Dickinson et al, 2014). Informasi perjalanan wisata yang wisatawan peroleh melalui smartphone perlu diidentifikasi kekuatan dan kelemahannya untuk dapat disesuaikan dengan kebutuhuhan informasi wisatawan terkini. Fokus lain yang tidak kalah penting adalah, bagaimana aplikasi tersebut mampu memberikan layanan yang aman, handal, dan efisien (Torun, 2011).

Bali sebagai salah satu destinasi internasional memiliki potensi yang luar biasa untuk diceritakan melalui teknologi ini. Sejalan dengan Dickinson et al (2014) bahwa peran smartphone meimiliki peran yang mampu memfasilitasi keputusan berwisata dan perjalanan wisata tersebut. Bahkan dengan teknologi global positioning system (GPS), menjadikan akses wisata berbasis lokal dapat diakses dengan mudah melalui smartphone (Bae, 2010). Fokus lain yang tidak kalah penting adalah, bagaimana aplikasi tersebut 
mampu memberikan layanan yang aman, handal, dan efisien (Torun, 2011). Aplikasi wisata yang tertanam dalam smartphone, selain sebagai sarana promosi, juga dapat meningkatkan jati diri kepariwisataan Bali yang sarat akan daya tarik alam dan budayanya sebagai sebuah peluang yang harus dimanfaatkan secara optimal. Selain itu, dapat memfasilitasi wisatawan dalam perjalanan wisatanya, baik pre trip, on the way, dan after trip (Wang et al, 2011a). Dengan demikian, penting untuk dikaji preferensi wisatawan terhadap penggunaan smartphone sebagai alat perjalanan wisata ke Bali.

\section{TINJAUAN PUSTAKA}

Perkembangan Teknologi Informasi dan Komunikasi (TIK) terutama sejak hadirnya Internet, berkembang sedemikian pesat dan telah mempengaruhi berbagai pola aktifitas yang dijalankan oleh masyarakat. Pengembangan teknologi baik dari sisi aplikasi maupun perangkat keras terus dilakukan seiring dengan kebutuhan masyarakat yang semakin beragam. Kehadiran mobile technology seperti misalnya handphone, smartphone saat ini telah memberikan kesempatan dan kemudahan bagi masyarakat untuk mengakses informasi dan melakukan komunikasi kapanpun dan dimanapun. Bahkan diprediksi bahwa penggunaan teknologi mobile akan terus mengalahkan penggunakan teknologi desktop yang sampai saat ini masih ada (Russel, 2010a). Data prediksi yang dikeluarkan oleh Morgan Stanley Research memperlihatkan bahwa pengiriman perangkat keras komputer desktop dan notebook secara global, secara signifikan tergantikan oleh smartphone atau perangkat mobile phone pada tahun 2012 dan akan terus meningkat pada tahun berikutnya.

Prediksi Morgan Stanley Research ini didukung dengan beberapa statistik yang menunjukkan berbagai peningkatan penggunaan terutama terkait dengan mobile internet. Data yang diambil dari eMarketer bulan Mei 2011 oleh Russel (2011b) menunjukkan bawa pengguna mobile internet dan mobile phone di Asia Pasifik meningkat secara signifikan. Bahkan Russel (2011b) memprediksi bahwa pada tahun 2015 pengguna mobile internet di Asia akan mencapai 512 juta pengguna. Di Asia Tenggara sendiri menunjukkan bahwa perkembangan penggunaan internet dan mobile internet meningkat secara signifikan dalam 10 tahun terakhir. 15,30 persen pengguna internet di Asia berasal dari Asia Tenggara, sementara 3 besar pengguna internet di Asia masih dikuasai oleh China (50,5 persen), India (11,9 persen), dan Jepang (10 persen). Indonesia sendiri masuk ke peringkat keempat dengan 5,4 persen pengguna. Satu data menarik lainnya adalah bahwa dari Preetham Rai (2012) yang melaporkan bahwa pengguna Ipad terbesar adalah di Asia Tenggara, terutama di Singapura, Brunei Darussalam, dan Malaysia.

Data pengguna mobile internet tahun 2012 di Asia Pasifik seperti dikutip Statista (2012) dari Nielsen (2012) menunjukkan bahwa negara-negara di Asia Tenggara masuk dalam jajaran sepuluh terbesar. 10 (sepuluh) besar peringkat tersebut adalah Jepang (86 persen), Korea (80 persen), Hongkong (76 persen), China (75 persen), Malaysia (75 persen), Taiwan (72 persen), Singapore (70 persen), Vietnam (62 persen), Thailand (47 persen), dan Indonesia (22 persen). Data tersebut di atas memperlihatkan besarnya prosentase pengguna smartphone yang menggunakan mobile internet di Asia Tenggara termasuk mendominasi di wilayah Asia Pasifik (5 dari 10 berasal dari wilayah Asia Tenggara). Belum termasukk Filipina yang ada di peringkat ke 11 (20 persen) yang masih di atas India (11 persen).

Mengacu pada data-data tersebut tentu sangatlah jelas bahwa perkembangan mobile internet berbasis smartphone akan sangat potensial sebagai media promosi suatu produk seperti misalnya produk pariwisata. Dimana yang dimaksud dengan produk pariwisata antara lain : lokasi wisata, deskripsi wisata dalam bentuk verbal maupun visual. Ebner dalam Seaton dan Bennet (1996) mengungkapkan bahwa dalam sebuah informasi pariwisata yang bersentuhan dengan teknologi, penting bagi wisatawan untuk dapat mengakses lalu lintas dan cuaca setempat, produk wisatanya, event, restoran dan akomodasi, transportasi publik beserta jadwalnya, serta informasi lokal lainnya.

\section{METODE PENELITIAN}

Data yang dikumpulkan adalah data primer berupa kuesioner sistem informasi perjalanan wisata Bali berbasis smartphone 
yang telah digunakan wisatawan. Data yang dikumpulkan berupa data kuantititatif dan kualitatif. Adapun data kualitatif berupa hasil uraian berdasarkan hasil tinjauan pustaka, observasi, serta hasil kuesioner. Sedangkan data kuantitatif berupa data produk pariwisata Bali yang terintergrasi ke dalam sistem informasi yang telah ada.

Pengumpulan data dilakukan dengan metode kuesioner, yaitu menyebarkan kuesioner dengan skala pengukuran likert yang digunakan untuk mengukur sikap wisatawan terhadap sistem informasi perjalanan wisata berbasis smartphone (Sugiyono, 1999) dengan sampel lokasi yaitu : Kuta, Tanah Lot, serta Ubud. Dengan populasi tak terhingga dan tingkat kesalahan 5 persen (Sugiyono, 1999), maka jumlah sampel yang diambil kurang lebih sebanyak 350 kuesioner kepada wisatawan guna menganalisis preferensi wisatawan terhadap penggunaan smartphone sebagai alat perjalanan wisata.

Penelitian dilakukan dengan memverifikasi hubungan konseptual pariwisata, dalam hal ini teknologi informasi pariwisata terhadap kondisi empiris (Veal, 2006). Konsep teknologi informasi pariwisata yang disajikan dalam tinjauan pustaka dihubungkan dengan kondisi eksisting yang ada dengan pendekatan variabel penelitian. Sedangkan dalam tahap analisis dan sintesis digunakan motode deskriptif.

\section{HASIL DAN PEMBAHASAN}

Responden dalam penelitian ini sebanyak 350 orang, akan tetapi yang valid sebanyak 322 orang yang terdiri dari wisatawan domestik (44 persen) beserta wisatawan mancanegara (56 persen) yang datang ke Bali. Kebanyakan dari mereka datang ke Bali, 82 persen dengan tujuan untuk berlibur, sisanya sebesar 18 persen memiliki motif untuk bisnis, mengunjungi teman ataupun kerabat, serta motif lainnya. Fakta yang menarik dalam penelitian ini adalah 87 persen dari 322 orang responden telah menggunakan smartphone sebagai alat perjalanan wisata, sedangkan sisanya sebesar 23 persen masih menggunakan media cetak ataupun media konvensional lainnya di dalam berwisata. Dari 87 persen wisatawan yang menggunakan smartphone sebagai alat perjalanan wisata, sebanyak 41 persen wisatawan menggunakannya dalam merencanakan perjalanan wisata, seperti browsing destinasi wisata yang akan dikunjungi, baik gambar maupun informasi lainnya yang dibutuhkan. 48 persen wisatawan menggunakan fitur dalam smartphone untuk mencari dan melakukan pemesanan kamar beserta mencari restoran. Sisanya sebesar 11 persen dipergunakan untuk peta, ramalan cuaca, serta fitur Global Positioning System (GPS). Kebanyakan atau sebesar 72 persen menggunakan sistem operasi IOS, sedangkan sisanya sebesar 28 persen menggunakan sistem operasi Android maupun Windows Mobile, beserta Blackberry.

Dilihat dari sumber informasi tentang Bali, sebesar 53 persen wisatawan domestik menggunakan media internet sebagai bahan informasi, 36 persen berasal dari teman atau kerabat, dari travel guide sebesar 7 persen, sisanya sebesar 4 persen memperoleh informasi melalui airlines, tourist office, travel bureaus, serta lainnya. Sedangkan pada wisatawan mancanegara, sebesar 56 persen wisatawan mancanegara mengemukakan bahwa informasi tentang Bali diperoleh dari internet. Dari teman atau kerabat sebesar 32 persen, serta dari travel guide sebesar 9 persen. Sedangkan sisanya sebesar 3 persen ada yang memperoleh informasi dari airlines, tourist office, travel bureaus, embassy, serta lainnya.

Berdasarkan jenis kelamin wisatawan domestik, 43 persen merupakan wanita, dan sisanya sebesar 57 persen merupakan pria. Sedangkan wisatawan mancanegara juga didominasi oleh pria sebesar 55 persen, dan sisanya sebesar 45 persen merupakan wanita. Dari 142 wisatawan domestik tersebut, kebanyakan berasal dari Provinsi DKI Jakarta sebesar 32 persen, Jawa Timur sebesar 21 persen, Jawa Tengah sebesar 18 persen, Jawa Barat sebesar 12 persen, DI Yogyakarta sebesar 8 persen, Sumatera Utara sebesar 4 persen, serta Sulawesi Utara sebesar 5 persen. Sedangkan dari 180 wisatawan mancanegara terdiri dari wisatawan berkebangsaan Australia sebesar 20 persen, Korea Selatan sebesar 8 persen, Belgia sebesar 1 persen, Kanada sebesar 3 persen, Inggris sebesar 7 persen, Finlandia sebesar 1 persen, Prancis sebesar 8 persen, Jerman sebesar 7 persen, Belanda sebesar 16 persen, Cina sebesar 6 persen, Italia sebesar 3 persen, Jepang sebesar 1 persen, Malaysia sebesar 7 persen, Norwegia sebesar 1 persen, Selandia Baru sebesar 2 persen, 
Spanyol sebesar 1 persen, Swedia sebesar 3 persen, Swiss sebesar 2 persen, serta Amerika sebesar 5 persen.

Dilihat dari segi usia, wisatawan domestik dalam penelitian ini memiliki usia terendah 18 tahun dan tertinggi 67 tahun. Mereka terdiri dari usia 18-22 sebesar 25 persen, usia 23-27 sebesar 28 persen, usia 28-32 sebesar 19 persen, usia 33-37 sebesar 5 persen, usia 38-42 sebesar 9 persen, serta usia 42 tahun keatas sampai dengan 67 tahun sebesar 14 persen. Sedangkan wisatawan mancanegara memiliki usia terendah 18 tahun dan tertinggi 64 tahun. Adapun komposisinya, mereka terdiri dari usia 18-22 sebesar 28 persen, usia 23-27 sebesar 25 persen, usia 28-32 sebesar 22 persen, usia 3337 sebesar 11 persen, usia $38-42$ sebesar 10 persen, serta usia 42 tahun keatas sampai dengan 64 tahun sebesar 4 persen. Tingkat pendidikan wisatawan domestik terdiri dari SMA sebesar 21 persen serta sisanya sebesar 79 persen telah mengenyam pendidikan Universitas. Demikian pula wisatawan mancanegara didominasi latar belakang pendidikan Universitas sebesar 87 persen, sedangkan sisnya sebesar 13 persen memiliki latar belakang pendidikan SMA.

Dominasi penggunaan smartphone sebagai alat perjalanan wisata telah mengubah cara wisatawan dalam melakukan perjalanan wisata menjadi lebih menarik dan atraktif. Seperti yang disampaikan oleh Wang et al (2014), bahwa penggunaan smartphone dalam perjalanan adalah gabungan kompleks dari berbagai fungsi dan layanan informasi yang dibutuhkan wisatawan untuk berkomunikasi, sebagai hiburan, memfasilitasi kebutuhan wisatawan ketika berlibur serta pencarian informasi terkait perjalanan wisata. Berbagai developer aplikasi perjalanan wisata yang banyak tersedia di dunia maya, seperti tripadvisor, agoda, booking.com, traveloka, telah menempatkan posisi smartphone sebagai alat perjalanan wisata (Dickinson et al, 2014). Faktanya, 87 persen wisatawan yang datang ke Bali meletakkan fungsi smartphone secara optimal untuk memenuhi kebutuhan wisatawan dalam merencanakan perjalanan, selama perjalanan, dan setelah kembali ke negara asalnya.

Hampir sebagian besar wisatawan yang datang ke Bali telah merencanakan liburannya, yang artinya bahwa wisatawan antusias meraih informasi sebanyak-banyaknya tentang Bali sebelum mereka melakukan kunjungan, seperti fakta yang menunjukkan bahwa kata "where is Bali" disebutkan sebagai pertanyaan yang paling banyak dicari dalam mesin pencari Google di tahun 2016. Hal ini tidak terlepas dari faktor yang menurut Wang et al (2014), salah satunya adalah karakteristik pribadi wisatawan, seperti kepribadian, gaya hidup, serta penggunaan smartphone dalam kehidupan sehari-hari menggugah perilaku wisatawan dalam mengaktualisasikan perjalanan wisatanya. Dilihat dari sebaran usia wisatawan yang menggunakan smartphone dalam perjalanan wisata sangat didominasi oleh usia produktif, yang kesehariannya menempatkan smartphone sebagai asisten pribadi yang komunikatif, membantu menyelesaikan pekerjaan wisatawan, dan tetap menjaga hubungan wisatawan dengan keluarga dan teman dalam konteks jejaring sosial kekinian. Temuan ini sejalan dengan Wang et al (2014), bahwa motivasi intrinsik dan ekstrinsik adalah faktor paling mendasar yang mendorong wisatawan untuk menggunakan smartphone dalam memenuhi kebutuhan perjalanan wisatanya. Tanpa adanya motivasi ini, wisatawan tidak akan memerlukan smartphone sebagai alat perjalanan wisata. Kepercayaan wisatawan akan informasi yang tersedia secara online juga menjadi faktor pendorong wisatawan untuk mempercayakan alat ini sebagai online guide yang menuntun dimana mereka akan menginap, kemana mereka harus pergi, serta cuaca apa yang akan mereka hadapi selama melakukan perjalanan di Bali. Dominasi pria dalam penggunaan smartphone dalam aktivitas perjalanan wisata ke Bali sejalan dengan hasil penelitian dari Buglass et al (2017). Hal ini dapat disebabkan oleh faktor bahwa pria menempatkan smartphone dengan kecepatan informasi dan interaksinya bukan sebagai teknologi semata, akan tetapi sebagai pendamping digital untuk tetap terhubung ke dunia luar. Pria menurutnya secara psikologis selalu terdorong untuk memerikasa smartphone sebagai akibat dari rasa takut ketinggalan berita menarik di internet dan jejaring sosial, serta takut tidak eksis atau fear of missing out (FoMo).

Gretzel dalam Wang et al (2014) menyoroti penggunaan smartphone yang telah mengubah pengalaman wisatawan sehubungan dengan penggunaan informasi tersebut. 
Pertama, dengan tersedianya informasi secara online, wisatawan dapat dengan mudah menentukan pilihan sesuai kemampuannya untuk memilih hotel, restoran, maupun penunjuk arah kemana mereka harus pergi. Kedua, dalam kondisi yang tidak terduga, wisatawan dapat serta merta untuk mengambil keputusan mengubah rencana perjalanan yang awalnya direncanakan ke rencana cadangan. Kecanggihan smartphone dapat membantu menuntaskan kejadian tidak terduga ini, karena informasi dapat diakses wisatawan saat dalam perjalanan wisata. Menurut Wang et al (2014), dalam kondisi ini aktivitas perjalanan wisata menjadi lebih spontan atau menghasilkan perjalanan wisata yang tidak direncanakan. Ketiga, fitur smartphone yang telah dibekali dengan kecanggihan menyimpan momen apapun secara online, telah menempatkan smartphone untuk mampu mendokumentasikan berbagai pengalaman menarik wisatawan yang selanjutnya menempatkan wisatawan dalam posisi eksis di media sosial, umpan balik menjadikan penghargaan tersendiri bagi wisatawan. Dengan demikian, jika dibandingkan dengan era pra smartphone, pengalaman berbagi momen indah ketika berwisata terjadi setelah wisatawan tiba di negara asalnya. Fakta ini kembali ditegaskan bahwa sebagian besar wisatawan yang datang ke Bali telah mampu mengoptimalkan fungsi smartphone untuk merencanakan perjalanan, selama perjalanan, dan kembali ke negara asalnya.

Kemenpar (2015) mengungkapkan bahwa kemajuan teknologi informasi dan komunikasi belum optimal dimanfaatkan dalam mempromosikan destinasi pariwisata di dunia internasional, dikarenakan masih terbatasnya kesadaran dan kemampuan pemangku kepentingan pariwisata dalam memanfaatkan kemajuan teknologi dan informasi tersebut dalam mendukung promosi pariwisata. Oleh karena itu, sangat penting untuk dapat memanfaatkan teknologi informasi dan komunikasi ini untuk inventarisasi aset-aset kepariwisataan di Bali guna memberikan kepuasan yang optimal kepada wisatawan. Hal ini seiring dengan temuan dalam penelitian ini bahwa, wisatawan berpendapat perlunya integrasi kebutuhan perjalanan wisata dalam sebuah aplikasi yang tertanam dalam smartphone, seperti hotel, restoran, penunjuk arah, cuaca, kebutuhan keuangan, budaya lokal, serta kebutuhan lainnya secara real time yang dapat menumbuhkan kepercayaan perolehan informasi secara online.

\section{SIMPULAN DAN SARAN}

Wisatawan yang datang ke Bali telah meningkatkan penetrasi penggunaan internet yang terintegrasi ke dalam smartphone dalam perilaku berwisatanya. Kepercayaan terhadap informasi yang tersedia secara online menjadi sangat penting bagi wisatawan guna mengambil keputusan perjalanan wisata. Smartphone tidak hanya sebagai alat teknologi semata, akan tetapi telah menjadi alat perjalanan wisata (Dickinson et al, 2014) sekaligus panggung aktivitas sosial, kreativitas, pengalaman berlibur wisatawan dengan tetap terkoneksi dengan keluarga maupun teman walau terhalang jarak yang relatif berjauhan. Pergeseran tahapan perjalanan wisata telah berubah seiring kemajuan teknologi semenjak berkembangnya teknologi smartphone (Wang et al, 2014), wisatawan dapat dengan mudah menentukan pilihan sesuai kemampuannya untuk berwisata menyangkut pemilihan hotel, restoran, atraksi wisata secara online. Selanjutnya, wisatawan dapat secara spontan mengubah rencana perjalanan wisata akibat kejadian tak terduga yang dialaminya serta berbagi momen berwisata saat di lokasi wisatawan tersebut berada. Asupan informasi online yang tidak tersedia secara integral menjadi kendala dalam mempermudah pemenuhan kebutuhan wisatawan secara online ke Bali, salah satunya akibat pemangku kepentingan yang kurang optimal dalam memanfaatkan keberadaan teknologi informasi ini. Kelemahan dalam penelitian ini adalah pengambilan sampel wisatawan hanya terfokus pada destinasi yang populer di Bali. Untuk itu, ke depannya perlu juga dilihat bagaimana preferensi wisatawan pada destinasi yang kurang maupun tidak populer di Bali terhadap penggunaan smartphone sebagai alat perjalanan wisata.

\section{UCAPAN TERIMA KASIH}

Penulis mengucapkan terima kasih yang setinggi-tingginya kepada: Rektor Universitas Udayana, Ketua LPPM, Dekan Fakultas Pariwisata, yang telah memberikan bantuan moril dan materiil guna terselenggaranya penelitian Hibah Unggulan Udayana tahun 2017. 


\section{Kepustakaan}

Bae, K.Y., 2010. Self-Tour Service Technology based on a Smartphone. Journal of Intelligence and Information Systems, 16(4), pp.147-157.

Buglass, SL., Binder, JF., Betts, LR. and Uderwood, JDM., 2017. Motivators of online vulnerability: the impact of social network site use and FOMO. Computers in Human Behavior, 66, pp. 248255.ISSN 0747-5632

Dickinson, J.E., Ghali, K., Cherrett, T., Speed, C., Davies, N. and Norgate, S., 2014. Tourism and the smartphone app: Capabilities, emerging practice and scope in the travel domain. Current Issues in Tourism, 17(1), pp.84-101.

Kementerian Pariwisata RI (2015). Laporan Akuntabilitas Kinerja Instansi Pemerintah (LAKIP) 2015.

Veal, AJ. 2006. Research Methods for Leisure and Tourism: A Practical Guide. Pearson Education : England.

Picard, Michael. 2006. Bali, Pariwisata Budaya dan Budaya Pariwisata. Kepustakaan Populer Gramedia : Jakarta.

Plautz, Jessica. (2016, December 14-last update), "Where is Bali? And More Most-Googled Travel Questions in 2016, (Travel and Leisure), Available: http://www.travelandleisure.com/traveltips/googled-travel-questions (Accessed: 2017, February 2).

Sudarma, I., 2012. PERSEPSI WISATAWAN TERHADAP EFEKTIVITAS E-KIOS DESTINASI PARIWISATA BALI. Majalah Ilmiah Teknologi Elektro, 8(1).

Sugiyono, D., 1999. Metode Penelitian Bisnis. CV Alvabeta, Jakarta, 22.

Torun, D., 2011. Usage of Smartphone Applications in Tourism.

Wang, D., Park, S. and Fesenmaier, D., 2011. An examination of information services and smartphone applications. , Fesenmaier, DR., Zheng Xiang, 2014. Adapting to the mobile world: a model of smartphone use. Annals of Tourism Research, September 2014. 